\title{
The neurogenic Suppressor of Hairless DNA-binding protein mediates the transcriptional activation of the Enhancer of split Complex genes triggered by Notch signaling
}

\author{
Magalie Lecourtois and François Schweisguth ${ }^{1}$ \\ Institut Jacques Monod, Centre National de la Recherche Scientifique (CNRS), Université Paris 7, Denis Diderot, \\ 75251 Paris CEDEX 05, France
}

\begin{abstract}
The Notch protein $(\mathbf{N})$ acts as a transmembrane receptor for intercellular signals controlling cell fate choices in vertebrates and invertebrates. The signal of $\mathbf{N}$ activation may be transduced directly from the cell surface into the nucleus by an evolutionarily conserved transcription factor, Suppressor of Hairless [Su(H)], by its regulated nuclear import. $\mathrm{Su}(\mathrm{H})$ is shown here to play a direct role in the immediate response of the genome to $\mathbf{N}$ signaling in Drosophila. First, $\mathrm{Su}(\mathrm{H})$ mutant embryos derived from mutant germ-line clones exhibited a "neurogenic" phenotype of neural hypertrophy similar to the $N$ phenotype. Second, the lack of $N$ lateral signaling in these $S u(H)$ mutant embryos was associated with a failure to express the $m 5$ and $m 8$ genes from the Enhancer of split Complex $[E(s p l)-C]$. Finally, the $\mathrm{Su}(\mathrm{H})$ protein bound to the regulatory sequences of the $E(s p l)-C m 5$ and $m 8$ genes, and these binding sites were required for the activation of the $m 5$ and $m 8$ promoters in the ventral neuroectoderm. The expression of the $E(s p l)-C \mathrm{~m} 8$ gene was found to be similarly regulated by $\mathrm{Su}(\mathrm{H})$ during wing imaginal disc development. Thus, the transcriptional activation of these $E(s p l)-C$ genes by $\mathrm{Su}(\mathrm{H})$ appears to be a direct and relatively general response to the activation of $\mathrm{N}$. However, we also present evidence indicating that $\mathbf{N}$ signals in an $\mathrm{Su}(\mathrm{H})$-independent manner during mesectoderm formation.
\end{abstract}

[Key Words: Lateral inhibition; neurogenesis; neurogenic genes; transcriptional regulation; signal tranduction] Received June 13, 1995; revised version accepted August 31, 1995.

Cell-cell communication plays an essential role in cell fate specification during the development of metazoans. The Drosophila Notch (N) protein belongs to a family of transmembrane receptors conserved from nematode to vertebrates that regulate numerous cell fate decisions in these species (for a recent review, see Artavanis-Tsakonas et al. 1995). Receptors of the Notch family mediate both inductive signaling between cells having distinct identities and lateral signaling between equipotent cells. These receptors are activated by a family of structurally related transmembrane proteins. The developmental consequence of $\mathrm{N}$ activation has been studied in detail in Drosophila. The transient expression of a constitutively active form of $\mathrm{N}$ appears to temporarily prevent cell fate determination in the eye and in the ventral neuroectoderm of the embryo (Fortini et al. 1993; Struhl et al. 1993). Similarly, in Xenopus eggs and mammalian cultured cells, deregulated $\mathrm{N}$ activation interferes with cell

${ }^{1}$ Corresponding author. differentiation (Coffman et al. 1990; Kopan et al. 1994; Nye et al. 1994). This led to the finding that $\mathrm{N}$ acts as a relatively general inhibitor of cell differentiation, whose activity is regulated by extracellular membrane-bound ligands. For example, in the ventral neuroectoderm of the gastrulating Drosophila embryo, the activation of $\mathrm{N}$ by its ligand Delta (Dl) is thought to inhibit the ability of uncommitted epithelial cells to delaminate and adopt a neural fate (Struhl et al. 1993). The competence to become neural is conferred on clusters of neuroectodermal cells by the dynamic expression of one or many basic helix-loop-helix region (bHLH) transcriptional activators encoded by the achaete-scute gene complex (AS-C). A high level of AS-C proteins results in the adoption of a neural fate (Martin-Bermudo et al. 1991, 1995; Skeath and Carroll 1992; Skeath et al. 1992), whereas the level of AS-C proteins remains low in the non-neural cells as the result of $\mathrm{N}$ negative signaling (Skeath and Carroll 1992; Campos-Ortega 1993; Martin-Bermudo et al. 1995). Genetic analyses have identified a few loci that encode putative components of the $\mathrm{N}$ signaling pathway 
(for review, see Artavanis-Tsakonas et al. 1995), including the Suppressor of Hairless $[\mathrm{Su}(\mathrm{H})]$ and Enhancer of split Complex $[E(s p l)-C]$ loci. Thus, the zygotic loss of $\mathrm{Su}(H)$ function results in early pupal lethality associated with a lack of negative $\mathrm{N}$ signaling, termed lateral inhibition, leading to neural hypertrophy (Schweisguth and Posakony 1992, 1994; Schweisguth 1995). The autonomous behavior of $\mathrm{Su}(H)$ mutant cells indicates that $\mathrm{Su}(H)$ is required for signal transduction during lateral inhibition in the pupal notum (Schweisguth 1995). $N$ and $\mathrm{Su}(H)$ also exhibit dose-sensitive genetic interactions in this and other developmental processes /Fortini and Artavanis-Tsakonas 1994; M. Gho and F. Schweisguth, unpubl.). Finally, the transient overexpression of either $\mathrm{Su}(H)$ or $N$ function prevents sensory organ precursor cells (SOPs) specification (Rebay et al. 1993; Schweisguth and Posakony 1994; M. Gho and F. Schweisguth, unpubl.). $S u(H)$ encodes an evolutionarily conserved sequence-specific DNA-binding protein (Matsunami et al. 1989; Schweisguth and Posakony 1992; Brou et al. 1994; Henkel et al. 1994), that binds directly to the ankyrin repeats of the intracellular domain of $\mathrm{N}$ (Fortini and Artavanis-Tsakonas 1994). In transfection studies, $\mathrm{Su}(\mathrm{H})$ colocalized with $\mathrm{N}$ in the cytoplasm of S2 cells. However, when Dl-expressing cells bound to $\mathrm{N}$-expressing cells, the cytoplasmic $\mathrm{N}-\mathrm{Su}(\mathrm{H})$ interaction was relieved, and $\mathrm{Su}(\mathrm{H})$ was detected mostly in the nucleus (Fortini and Artavanis-Tsakonas 1994). This suggested that the $\mathrm{N}$-regulated nuclear import of $\mathrm{Su}(\mathrm{H})$ into the nucleus may transduce the $\mathrm{N}$ signal directly from the membrane into the nucleus (Artavanis-Tsakonas et al. 1995). Therefore, which are the genes that are directly activated or repressed by $\mathrm{Su}(\mathrm{H})$ in response to $\mathrm{N}$ activation? Direct cellular target genes of $\mathrm{Su}(\mathrm{H})$ have only been identified in human B cells where they are thought to act as a transcriptional repressor (Dou et al. 1994; Hsieh and Hayward 1995). However, its repression activity can be suppressed with Epstein-Barr virus infection, through direct protein-protein interaction with the viral trans-activator protein EBNA2. EBNA2 binding not only masks the $\mathrm{Su}(\mathrm{H})$ repression domain but also provides an activation function to the DNA-bound EBNA2-Su(H) complex (Hsieh and Hayward 1995). This function of human $\mathrm{Su}(\mathrm{H})$ apparently does not relate to $\mathrm{N}$ signaling activity. In Drosophila, although there are not yet any known direct $\mathrm{Su}(\mathrm{H})$ target genes, the target genes of $\mathrm{N}$ signaling include those from the $E(s p l)-\mathrm{C}$. The $E(s p l)-\mathrm{C}$ acts genetically downstream of $N$ in the neurogenic pathway (de la Concha et al. 1988; Lieber et al. 1993). It encodes seven functionally redundant bHLH transcriptional regulators [E(spl)-C $\mathrm{m} \delta, \mathrm{m} \gamma, \mathrm{m} \beta, \mathrm{m} 3, \mathrm{~m} 5, \mathrm{~m} 7$, and $\mathrm{m} 8]$, and one unrelated protein [E(spl)-C m4] (Delidakis et al. 1991; Delidakis and Artavanis-Tsakonas 1992; Knust et al. 1992; Schrons et al. 1992). At least one of these neurogenic bHLH E(spl)-C proteins (mo) has been shown to accumulate in response to the activation of $\mathrm{N}$ in the neuroectoderm of stage 9 embryos (Jennings et al. 1994). In this report we identify a strict genetic requirement for $\mathrm{Su}(\mathrm{H})$ activity for cell fate choices during early neurogenesis. Homozygous mutant embryos derived from mu- tant maternal germ-line clones exhibited a "neurogenic" phenotype of neural hypertrophy, indicative of a failure in lateral inhibition. Furthermore we show that the $\mathrm{Su}(\mathrm{H}) \mathrm{DNA}$-binding protein mediates directly the $\mathrm{N}$-dependent transcriptional activation of at least two bHLH $E(s p l)-\mathrm{C}$ genes. The $\mathrm{Su}(\mathrm{H})$ protein binds specifically to several sites within the regulatory sequence of the $E$ (spl)-C $m 5$ and $m 8$ genes. These binding sites were found to be required for the $S u(H)$-dependent regulation of the $E$ (spl)-C $m 5$ and $m 8$ genes during both early neurogenesis in the embryo and imaginal disc development. This constitutes the first molecular characterization of the immediate response of the genome to $\mathrm{N}$ signaling. Finally, we show that the $N$-dependent transcription of the single-minded (sim) gene in midline cells does not require $\mathrm{Su}(\mathrm{H})$ activity, suggesting that $\mathrm{N}$ can signal in an $\mathrm{Su}(H)$-independent manner during mesectoderm formation.

\section{Results \\ The "neurogenic" function of $\mathrm{Su}(\mathrm{H})$ during early neurogenesis}

The complete lack of $\mathrm{Su}(H)$ zygotic function results in early pupal lethality and failure in lateral inhibition (Schweisguth and Posakony 1992, 1994; Schweisguth 1995). Because $\mathrm{Su}(\mathrm{H})$ is strongly expressed maternally (Schweisguth and Posakony 1992), we investigated the putative embryonic function of $S u(H)$ in embryos derived from $S u(H)$ null mutant germ-line clones. These were produced using the autosomal FLP-Dominant Female Sterile technique (Chou and Perrimon 1992; Xu and Rubin 1993; Hou et al. 1995) (see Materials and methods for details|. Embryos homozygous mutant for $\mathrm{Su}(\mathrm{H})$ derived from these germ-line clones, hereafter referred to as $\mathrm{Su}(\mathrm{H})$ mutant embryos, did not hatch. Instead they exhibited a strong "neurogenic" cuticular phenotype (Lehmann et al. 1983). Cuticle was not detected ventrally (Fig. 1A). The dorsal cuticle, including tracheal pits, appeared almost normal, whereas in the head region, only a few disorganized cuticular pieces were observed. In contrast, the embryos that were heterozygous for $\mathrm{Su}(H)$ gave rise to adult flies (data not shown). Therefore, a single paternal copy of $S u(H)$ fully rescued the lack of maternal activity (see also Fig. 1D,F). Along with the observation that the maternal contribution of $S u(H)$ compensates for the lack of zygotic activity in the embryo, the $\mathrm{Su}(\mathrm{H})$ protein is thought to be stable or is required in small amounts in the embryo.

In the $S u(H)$ mutant embryo, the number of neuroblasts and sensory precursors that segregate from the ventral and dorsolateral neuroectoderm, respectively, is greatly increased, as shown by the expression of the panneural enhancer-trap marker 439 (Kunish et al. 1994) (Fig. 1B,C). This leads to a hypertrophy of the central and peripheral nervous systems and a concomitant failure of the ventral and head epidermis to develop; hence, the neurogenic cuticular phenotype. In Figure 1E, we show that the peripheral neurons were detected in excess 
Figure 1. The $S u(H)$ "neurogenic" phenotype. In all $S u(H)$ mutant embryos $(A-C, E)$, both the maternal and zygotic $\mathrm{Su}(H)$ contributions have been removed genetically. Anterior is to the left. (A) Cuticular preparation showing the strong neurogenic phenotype of $S u(H)$. Cuticle was observed in the dorsal-posterior region, along with some cuticular pieces left in the head region. $(B, C)$ Anti- $\beta$-galactosidase staining of $S u(H) \mathrm{mu}$ tant embryos carrying one copy of the the panneural enhancer-trap marker 439 (Kunish et al. 1994). Neural hypertrophy underlies the lack of secreted cuticle. $(B)$ An excess number of neuroblasts is visible in the dorsal view of a late stage 10 embryo. $(C)$ A ventro-lateral surface view of a mutant stage 14 embryo shows that all cells of the ventral neurogenic region have adopted a neural fate. Supernumerary sensory neural cells are also visible in the dorsolateral ectoderm. $(D)$ Surface view of a stage 14 embryo derived from mutant germ-line clones but rescued by a wildtype paternal copy of $S u(H)$ showing the expression pattern of the 439 enhancer-trap marker.

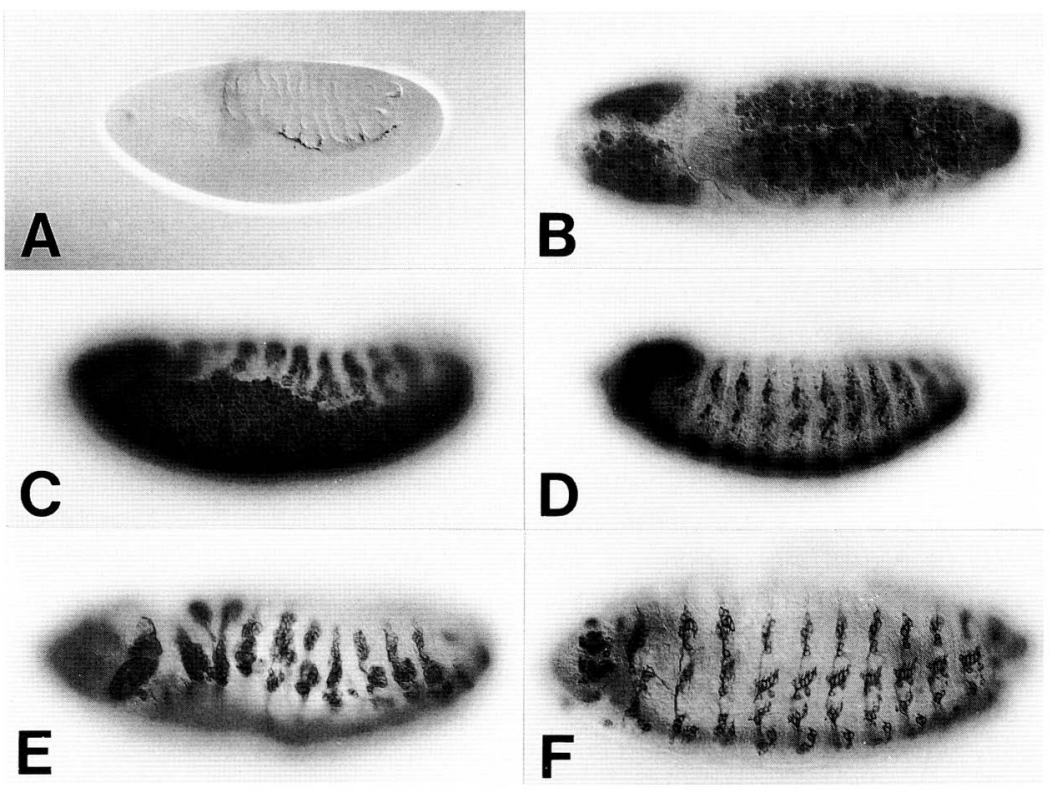
This pattern of expression is similar to the one seen in the wild-type embryos from the 439 line. $(E) 22 \mathrm{ClO}$ immunostaining of a Su(H) mutant stage 15 embryo. The hypertrophy of the peripheral nervous system in $\mathrm{Su}(H)$ mutant embryos is shown using the $\mathrm{mAb} 22 \mathrm{C} 10$ that specifically labels sensory neurons. $(F) 22 \mathrm{Cl0}$ immunostaining of a stage 15 embryo derived from mutant germ-line clones but rescued by a wild-type paternal copy of $S u(H)$. This embryo appears identical to a wild-type embryo.

number using a neuronal-specific antibody mAb $22 \mathrm{C} 10$ (Zipurski et al. 1984). In contrast, no defect was detected in the nervous system of the sibling embryos rescued by the wild-type paternal copy of $S u(H)$ (Fig. 1D, F).

\section{Proneural gene expression in $\mathrm{Su}\langle\mathrm{H}|$ mutant embryos}

The determination of an excess number of neural precursor cells correlates with defects in the expression of the achaete $(a c)$ and scute $(s c)$ genes analyzed by in situ hybridization. In early stage 9 wild-type embryos, $a c$ is expressed in a repeating pattern of four clusters of five to seven ectodermal cells per hemisegment. By late stage 9 , ac expression resolves to a single neuroblast in each cluster (Skeath and Carroll 1992) (Fig. 2A,C). In Su(H) mutant embryos derived from germ-line clones, high levels of $a c$ transcript were seen in four clusters of four to eight enlarged cells per hemisegment at late stage 9 (Fig. 2B,D). Also, occasionally, the two ventral-most clusters fused at the midline (arrowhead in Fig. 2B). These ac-expressing cells are neuroblasts delaminating from the neuroectoderm (Fig. 2D). Similar defects were seen in the accumulation profiles of the $s c$ transcript and of the ac protein (not shown). Thus, $S u(H)$ activity is necessary to restrict $a c$ and $s c$ expression to single cells. Previously, a similar phenotype was described for a complete loss of $N$ activity (Lehmann et al. 1983; Skeath and Carroll 1992; Campos-Ortega 1993). Therefore, we conclude that $\mathrm{Su}(\mathrm{H})$ activity is strictly required for the $\mathrm{N}$-dependent segregation of cell fates during early neurogenesis. This deregulation of $a c$ expression is also highly reminiscent of the high-level accumulation of the ac protein that was seen in most or all proneural cluster cells in $\mathrm{Su}(\mathrm{H}) \mathrm{mu}-$ tant imaginal discs (Schweisguth and Posakony 1994). Thus, $\mathrm{Su}(H)$ may play a similar role in $\mathbf{N}$ signaling during early neurogenesis in the embryo and peripheral neurogenesis in the pupa (Schweisguth 1995).

The expression of the $a c$ and $s c$ genes by midline cells (arrowhead in Fig. 2B; data not shown) suggests that the neuroectoderm may extend ventrally into the territory normally occupied by the mesectoderm at the midline. The mesectoderm forms during gastrulation when two single-cell-wide rows join at the midline. These cells specifically express the sim gene (Fig. 2E) that controls mesectoderm formation (Nambu et al. 1991). Mesectoderm formation and sim expression at the midline are known to depend on $\mathrm{N}$ signaling (Menne and Klämbt 1994; Martin-Bermudo et al. 1995). To investigate the role of $\mathrm{Su}(H)$ in mesectoderm specification, the expression of $\operatorname{sim}$ was analyzed by in situ hybridization in stage 8 embryos. Most midline cells of $S u(H)$ mutant embryos expressed sim in a manner similar to wild-type embryos (Fig. 2F). However, a few cells from this two-cell-wide row failed to express sim (arrowhead in Fig. 2F). These rare interruptions in sim expression correlate well with the occasional fusions of the clusters of ac-expressing cells at the midline. Thus, in contrast with $N, S u(H)$ activity appears to be largely dispensable for both sim expression and mesectoderm formation.

The neuroectodermal expression of at least two $\mathrm{E}(\mathrm{spl})-C$ genes requires $\mathrm{Su}(\mathrm{H})$ function

All $E(s p l)$-C genes, with the exception of $E(s p l)$-C $m 3$, exhibit similar expression patterns in the neuroectoderm 


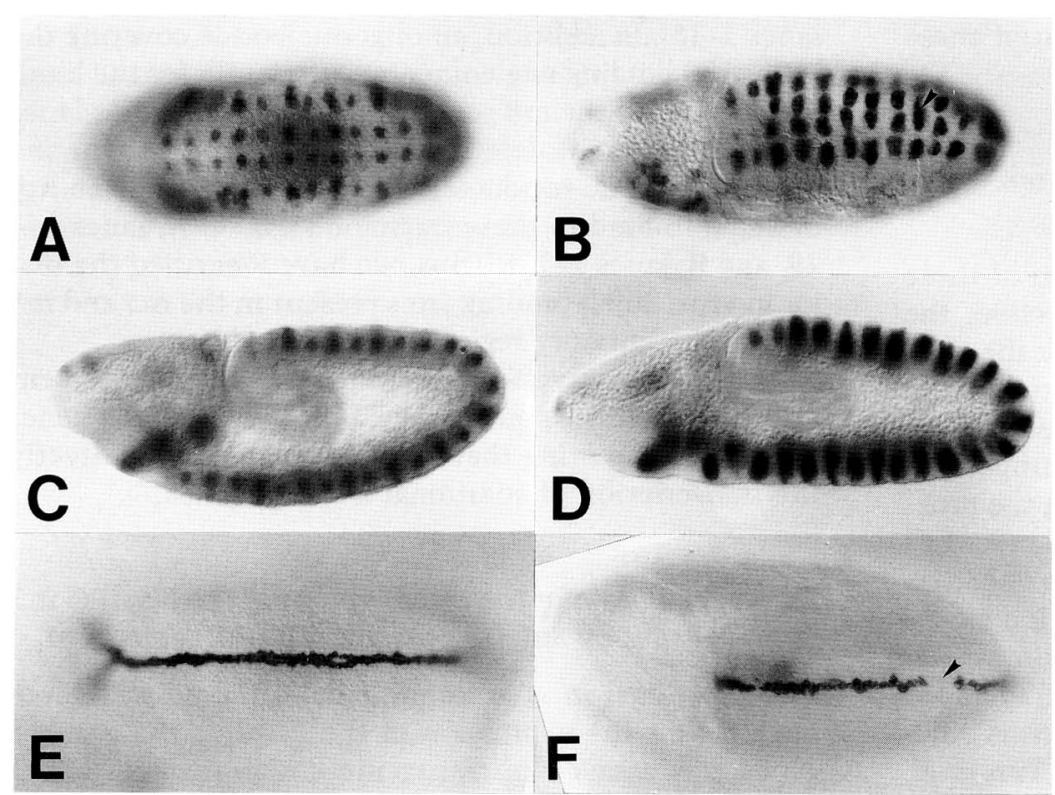

Figure 2. Expression of the $a c$ and sim genes in $\mathrm{Su}(H)$ mutant embryos. In situ hybridization of wild-type $(A, C, E)$ and $S u(H)$ mutant embryos derived from germ-line clones $(B, D, F)$. The spatial distribution of the $a c(A-D)$ and $\operatorname{sim}(E, F)$ transcripts is shown. $(A)$ Ventral view of a wild-type stage 9 embryo. Singled-out SI neuroblasts specifically accumulate ac transcripts. $(B)$ Dorsal view of a $S u(H)$ mutant stage 9 embryo. Four clusters of four to eight cells per hemisegment express $a c$ at a very high level. At the midline, most cells occupying the position of the mesectodermal cells apparently did not express $a c$. In a few cases, however, some of the medial clusters fuse at the midline (arrowhead). $(C)$ Midsagittal view of a wild-type stage 9 embryo. The $a c$-expressing neuroblasts have clearly delaminated from the neuroectoderm. $(D)$ Midsagittal view of an $\mathrm{Su}(H)$ mutant stage 9 embryo. Most of the $a c$-expressing neuroblasts have delaminated from the ectodermal cell layer at this stage. $(E)$ Spatial distribution of the sim transcript in a wild-type stage 8 embryo (ventral view). The two single-cell-wide rows are joined at the midline. $(F) \operatorname{sim}$ expression in a $S u(H)$ mutant late stage 8 embryo (dorsal view). Only a few midline cells do not express $\operatorname{sim}$ (arrowhead). Embryos homozygous mutant for $\mathrm{Su}(\mathrm{H})$ (i.e., that do not carry the $\mathrm{CyO}$ wg-lacZ balancer) (see Materials and methods), were unambiguously identified using a lac $Z$ RNA probe.

at stages 8-10 (Knust et al. 1992). At stage 9, the $E$ (spl)-C $m 5$ and $m 8$ genes are expressed in most ventral neuroectodermal cells in a ladder-like pattern. Their expression immediately precedes and follows the first wave of neuroblast segregation (SI) (Fig. 3A,B). With the possible exception of $m 8$, these $E$ (spl)-C transcripts do not accumulate in the delaminating neuroblasts (Knust et al. 1992; Tata and Hartley 1993). Because the expression of (at least) the E(spl)-C m $\delta$ protein appeared to be dependent on $\mathrm{N}$ signaling activity at this stage (Jennings et al. 1994|, we investigated whether $\mathrm{Su}(H)$ was required for the expression of these $E(s p l)$-C genes. In $S u(H)$ mutant embryos derived from mutant germ-line clones, the accumulation of the $E(s p l)-\mathrm{C} m 5$ transcripts was greatly reduced in the ventral neuroectoderm at stages 8-10 (Fig. $3 \mathrm{C}, \mathrm{E})$. Similarly, expression of the $E$ (spl)-C $\mathrm{m} 8$ gene appeared very weak and transient in a few cells that might correspond to SI neuroblasts, that delaminate in an excess number in the $\mathrm{Su}(\mathrm{H})$ mutant embryos (Fig. 3D,F). The expression of the $E(\mathrm{spl})$-C $\mathrm{m} 7$ gene was also affected in a manner similar to that of $E(s p l)-C \mathrm{~m} 5$ (data not shown). Therefore, the $\mathrm{Su}(H)$ activity is strictly required

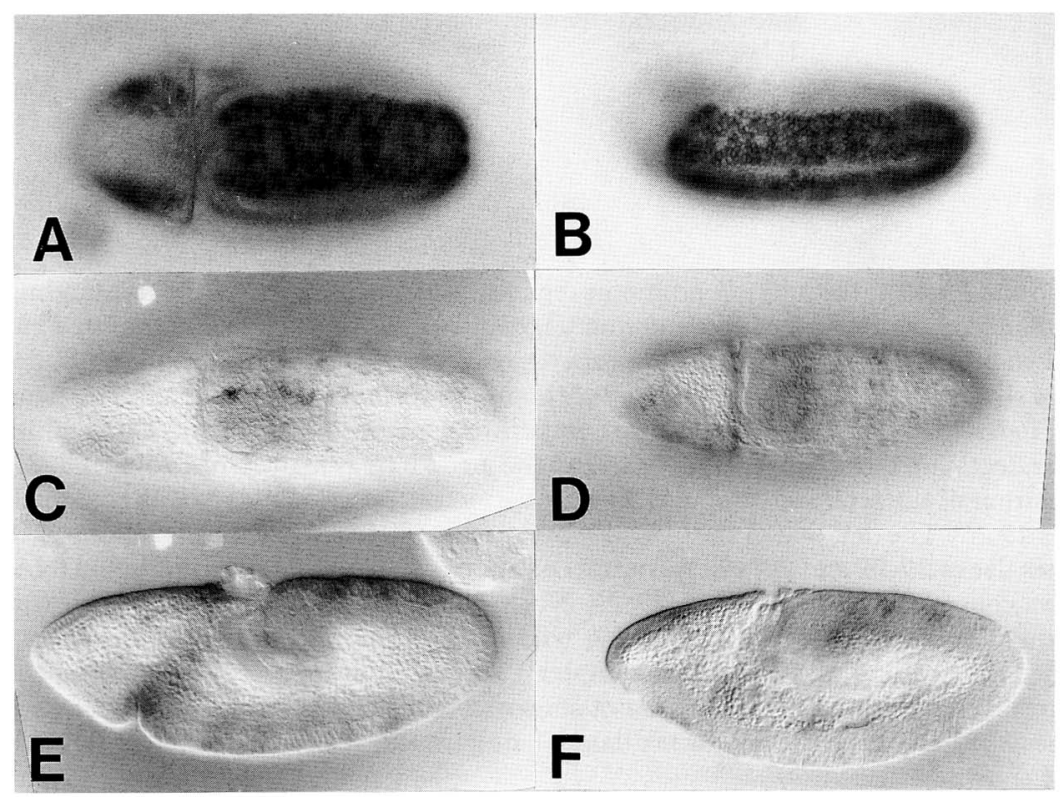

Figure 3. Expression of the $E(s p l)-\mathrm{C} m 5$ and $m 8$ genes in $S u(H)$ mutant embryos. In situ hybridization of wild-type $(A, B)$ and $S u(H)$ mutant embryos derived from germ-line clones $(C-F \mid$. The spatial distribution of the $E(s p 1)-\mathrm{C} m 5 \quad(A, C, E)$ and $m 8(B, D, F)$ transcripts is shown in stage 9 embryos. A very strong reduction in $E$ (spl)-C $m 5$ and $m 8$ transcript accumulation was seen in the neuroectoderm of $S u(H)$ mutant embryos. 
for the high-level neuroectodermal expression of these bHLH $E($ spl)-C genes.

The regulatory regions of the $\mathrm{E} / \mathrm{spl} \mid-\mathrm{C} \mathrm{m} 5$ and $\mathrm{m} 8$ genes contain in vitro binding sites for $\mathrm{Su}(\mathrm{H})$

Could this effect of $\mathrm{Su}(\mathrm{H})$ on the transcription of these $E(s p l)$-C genes be direct? To address this question, the $\mathrm{m} 5$ and $\mathrm{m} 8$ promoter regions were analyzed for the presence of $\mathrm{Su}(\mathrm{H})$ in vitro binding sites. These two genes were chosen because their regulatory sequences have already been characterized (Kramatschek and Campos-Ortega 1994). Genomic DNA fragments covering the proximal regulatory regions of the $E(s p l)-\mathrm{C} m 5$ and $m 8$ genes (from positions -897 to +20 , and -1166 to +87 , respectively) were used as probes in gel retardation experiments using the in vitro-translated $\mathrm{Su}(\mathrm{H})$ protein (Fig. 4). Each genomic fragment that bound to $\mathrm{Su}(\mathrm{H})$ included a motif identical, or very similar, to the consensus binding site defined for its mammalian homolog (Tun et al. 1994) (Table 1). Four and three putative binding sites were identified in these $m 5$ and $m 8$ promoter regions, respectively. In vitro, $\mathrm{Su}(\mathrm{H})$ bound strongly to these $m 8$ putative sites in a sequence-specific manner (Fig. 4A, lanes 1-15). In addition, an oligonucleotide covering the $m 8-180$ binding site competed efficiently for the binding of $\mathrm{Su}(\mathrm{H})$ to the $m 8$ genomic fragments (Fig. 4A, lanes $19,26)$. Finally, the deletion of these sites within the $m 5$ and $m 8$ genomic regulatory regions abolished the ability of $\mathrm{Su}(\mathrm{H})$ to bind to these fragments (Fig. 4, A, lanes 1629 , and $B$, lanes $1-12$ ). Thus, we have identified the major in vitro $\mathrm{Su}(\mathrm{H})$-binding sites present in the $\mathrm{m} 5$ and $m 8$ proximal regulatory regions.

Notably, putative $\mathrm{Su}(\mathrm{H})$-binding sites are also present in the promoter regions of the $E$ (spl)-C $m 4$ and $m \gamma$ genes (Table 1), suggesting that $\mathrm{Su}(H)$ might regulate directly the transcription of additional $E$ (spl)-C genes.

Direct regulation of the transcription of the $\mathrm{E} / \mathrm{spl} /-C \mathrm{~m} 5$ and $\mathrm{m} 8$ genes by $\mathrm{Su}(H)$ in the ventral neuroectoderm

The functional in vivo importance of these $\mathrm{Su}(\mathrm{H})$-binding sites for the expression of the $E(s p l)-C m 5$ and $m 8$ genes was assayed in transgenic embryos. The $-897 /$ $+20 \mathrm{~m} 5$ and $-1166 /+87 \mathrm{~m} 8$ promoter regions conferred dynamic patterns of transcript accumulation to a lac $Z$ reporter gene that appeared very similar to those seen for the endogenous genes at stages 8-10. Two lon-
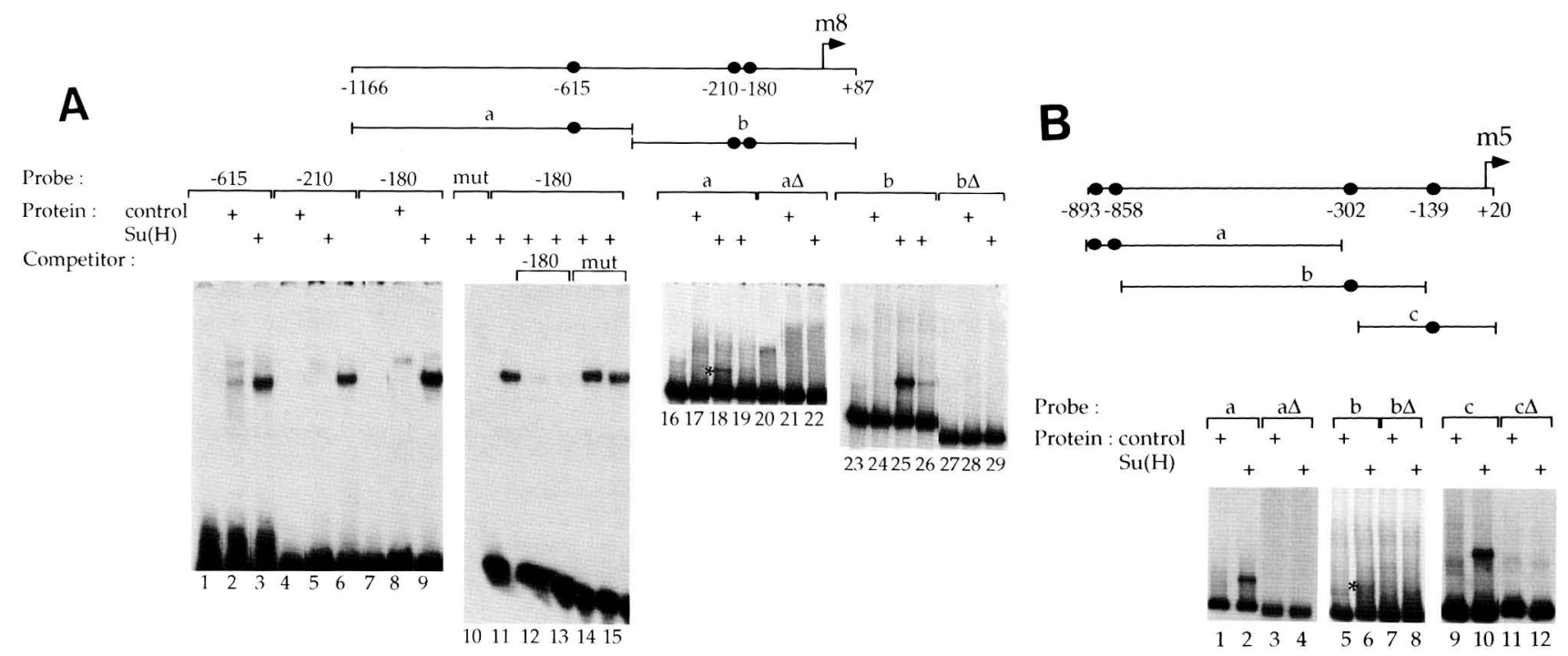

Figure 4. Identification of the $\mathrm{Su}(\mathrm{H})$ binding sites in the $E(s p l)-\mathrm{C} m 8$ and $m 5$ promoter regions. $(A)$ Identification of the $m 8$-binding sites for $\mathrm{Su}(\mathrm{H})$. The -615 and -210 and -180 oligonucleotides, as well as the genomic fragments EcoRI-BamHI (a and mutated a $\Delta$ ) and BamHI-Asp718 (b and mutated $\mathrm{b} \Delta$ ), were used as probes in the gel retardation experiments shown below the map. The Su(H) protein bound to the -615 (lanes 1-3), -210 (lanes 4-6) and -180 probes (lanes 7-9,11) but not to the mut probe (lane 10). This binding was competed by a $20 \times$ (lane 12) or a $100 \times$ (lane 13) molar excess of specific competitor. However, a $20 \times($ lane 14 ) or $100 \times$ (lane 15) molar excess of the mut competitor had no effect. Su(H) also specifically bound to the a and b fragments (lanes 16-19,23-25, respectively: the asterisk in lane 18 indicates the position of the retarded complex). The formation of these complexes was competed by a $20 \times$ molar excess of the -180 competitor (lanes 19,26 ). The deletion of the $-615,-210$, and $-180 \mathrm{Su}(\mathrm{H}$ ) consensus binding site sequences abolished the formation of these complexes (lanes 20-22 and 27-29). A truncated version of Su(H) that does not bind DNA, $\mathrm{Su}(\mathrm{H})$ 10-399 (Brou et al. 1994) was used as a negative control in lanes 1, 4, 7, 16, 20, 23, 27. (B) Identification of the m5-binding sites for $\mathrm{Su}(\mathrm{H})$. The $\mathrm{Su}(\mathrm{H})$ in vitro-translated product bound specifically to the $\mathrm{a}, \mathrm{b}$, and $\mathrm{c}$ wild-type genomic fragments from the $\mathrm{m} 5$ promoter (lanes 1, 2, 5, 6, 9, 10; the asterisk indicates the position of the retarded complex). This binding appeared to be dependent on the presence of each of the four $\mathrm{Su}(\mathrm{H}$ ) binding sites (lanes 3, 4, 7, 8, 11,12; data not shown). Nucleotide positions are given with respect to mRNA start site positions. Binding to the -302 site appears to be weak (lane 6), despite the strong binding of $\mathrm{Su}(\mathrm{H})$ to a 18-mer oligonucleotide probe covering this site (not shown). 
Table 1. The E(spl)-C binding sites for $\mathrm{Su}(H)$

\begin{tabular}{lc}
\hline \multicolumn{2}{c}{$S u(H)$ binding sites } \\
m8 $(-615)$ & 5'-CTGTGGGAACG \\
m8 $(-210)$ & 5'-GTGTGAGAAAC \\
m8 $(-180)$ & 3'-GCGTGGGAACC \\
m5 $(-893)$ & 5'-GCGTGGGAAAC \\
m5 $(-858)$ & 3'-TCGTGAGAACC \\
m5 $(-302)$ & 3'-ACGTGGGAACG \\
m5 $(-139)$ & 3'-GCGTGGGAAAG \\
Consensus: & C/TGTGG/AGAAC/A \\
Putative Su(H) binding sites \\
m $\gamma(-708)$ & 3'-CTGTGGGAACA \\
m $\gamma(-531)$ & 5'-TCGTGGGAACC \\
m $\gamma(-306)$ & 3'-TCGTGGGAAAC \\
m4 $(-84)$ & 3'-GTGTGGGAACT \\
\hline
\end{tabular}

The sequences of the $E(s p l)-\mathrm{C} m 5$ and $m 8$ binding sites for $\mathrm{Su}(\mathrm{H})$, as well as the additional putative sites present in the $E$ (spl)-C $m \gamma$ and $m 4$ genes, are shown. The positions given for these sites correspond to the position of the $5^{\prime}-\mathrm{G}$ nucleotide with respect to the transcriptional start site. The core consensus sequence, GTGG/AGAA, initially defined for the mouse and human $\mathrm{Su}(\mathrm{H})$ homolog consensus binding site (Ling et al. 1994; Tun et al. 1994) appears in boldface type. The consensus derived from these $E(s p l)-\mathrm{C}$ binding sites for $\mathrm{Su}(\mathrm{H})$ is shown underneath. In Drosophila, the core consensus is flanked by a $\mathrm{C}$ or a $\mathrm{T}$ nucleotide at the $5^{\prime}$ end and a $\mathrm{C}$ or an A residue at its $3^{\prime}$ end, similar to that in vertebrates (Tun et al. 1994). The $m 8(-210)$ and $\mathrm{m} 5(-858)$ sites carry an A residue (instead of a G) at the fourth position within the core consensus sequence. This position similarly appeared to be the less conserved one within the mouse protein consensus, for which this $\mathrm{G}$ can be replaced by either an A or a T residue (Tun et al. 1994). gitudinal rows of ectodermal cells on either side of the midline, with some additional cells located in between these two rows, expressed lac $Z$ in stage 9 embryos (Fig. 5A, B, G, and $\mathrm{H}$; cf. Fig. 3A and B). The $m 8-l a c Z$ construct was also expressed in the delaminating SI neuroblasts at stage 9. The deletion of all the $\mathrm{Su}(\mathrm{H})$-binding sites within the $m 5$ and $m 8$ promoter regions, hereafter denoted $m 5 m u t$ and $m 8$ mut, caused a marked reduction in lac $Z$ expression in the neuroectoderm (Fig. 5C,D,I,J). At stage 9, the m5mut-lacZ construct was expressed weakly in the neuroectoderm, in a pattern of pair-rule stripes (Fig. $5 \mathrm{C}$ and D). In m8mut$1 a c Z$ embryos, there was a pronounced reduction in lacZ expression in the neuroectoderm, but it was clearly detected in the delaminating SI neuroblasts (Fig. 5I,J). These results show that the $\mathrm{Su}(\mathrm{H})$-binding sites are required for the high-level expression of the $E$ (spl)-C m5 and $m 8$ genes in the ventral neuroectoderm. However, these binding sites are not necessary for $E(s p l)-C \mathrm{~m} 8 \mathrm{ex}$ pression in the SI neuroblasts. Therefore, the transcriptional activation of these genes by $S u(H)$ appears restricted to cells that remain ectodermal and that do receive $\mathrm{N}$ signaling.

We then tested the effect of $S u(H)$ on $m 5-l a c Z$ and $m 8-1 a c Z$ expression at stage 9. In mutant embryos derived from germ-line clones, $m 5-l a c Z$ and $m 8-l a c Z$ expression was nearly abolished (Fig. 5E, F, K, L), except for a transient expression of $m 8-l a c Z$ in the supernumerary SI neuroblasts (Fig. $5 \mathrm{~K}, \mathrm{~L}$ ). Thus, the removal of either the $\mathrm{Su}(\mathrm{H})$ activity or the binding sites for $\mathrm{Su}(\mathrm{H})$ has very similar consequences for the activity of the $m 8$ pro-
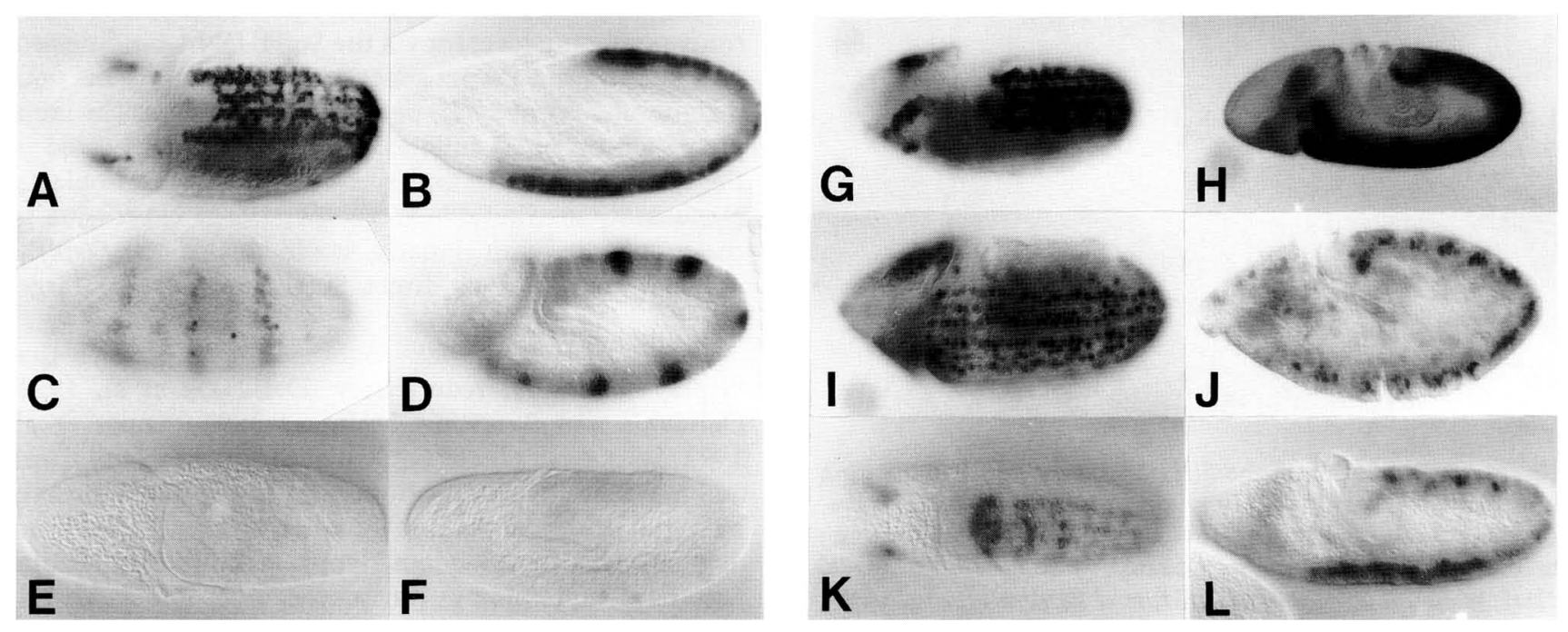

Figure 5. Regulation of the $E(s p l)-C m 5$ and $m 8$ genes by $\mathrm{Su}(\mathrm{H})$ in stage 9 embryos. The distribution of $l a c Z$ transcripts is shown in dorsal $(A, E, G, K)$, ventral $(C, I)$, and lateral views $(B, D, F, H, J, L)$ of stage 9 embryos of the following genotypes: $(A, B) \mathrm{m5}-1 a c Z$ embryos. $(C, D) \mathrm{m} 5 \mathrm{mut}-\mathrm{lac} Z$ embryos. Weak ectodermal expression was seen first in a pair-rule pattern, then in all segments at stage 10 (not shown). The significance of this novel pattern of expression is not known. $(E, F) S u(H)$ homozygous mutant embryos derived from germ-line clones and carrying one copy of $m 5-l a c Z$. $(G, H) m 8-1 a c Z$ embryos. $(I, J)$ m8mut-lacZ embryos. Expression was restricted to the SI neuroblasts. $(K, L) S u(H)$ homozygous mutant embryos derived from germ-line clones and carrying one copy of $m 8-l a c Z$. lac $Z$ expression was detected in the SI neuroblasts that developed in an excess number in these mutant embryos. The accumulation of lac $Z$ RNA driven by the $m 5(A, B)$ and $m 8(G, H)$ promoters was similar to those seen for endogenous genes at this stage (cf. Fig. 3). Su(H) mutant embryos were obtained by crossing virgin $w^{1118} / w^{1118} h s-F L P 1 ; S u(H)^{S F 8} \mathrm{P}\left[\right.$ lacZ; $\left.w^{+}\right] \mathrm{A} 1-29$ FRT40A/P/ovo ${ }^{D 1} \mid 13 \times 13 \mathrm{FRT}$ T0A females to either $S u(H)^{S F 8} \mathrm{P}[\mathrm{m} 8-\mathrm{lacZ}]-1 / C y O \mathrm{wg}-\mathrm{lacZ}$ or $w^{1118} / \mathrm{Y}$; Su(H) ${ }^{A R 9} \mathrm{P}[\mathrm{m} 5-l a c Z] 15-5 / C y O w g-l a c Z$ males. 
moter. Both experimental conditions also affect the activity of the $\mathrm{m} 5$ promoter dramatically. The difference observed between the expression of $m 5-l a c Z$ in mutant embryos and m5mut-lacZ might suggest that weak binding sites for $\mathrm{Su}(\mathrm{H})$ are still present in the m5mut sequence. However, the expression of m5mut-lacZ is difficult to interpret, as it is not clear how it relates to the expression of the endogenous $E(s p l)-\mathrm{C} m 5$ gene. Together, these data indicate that $S u(H)$ regulates directly the high level expression of the $E(s p l)-C m 5$ and $m 8$ genes in the ventral neuroectoderm.

\section{Regulation of the imaginal disc expression of the $\mathrm{E}(\mathrm{spl})-\mathrm{C} \mathrm{m} 8$ gene by $\mathrm{Su}(\mathrm{H})$}

The $m 8-l a c Z$ construct was also expressed in imaginal discs of late third-instar larvae, in proneural cluster cells, as well as along the wing margin (Fig. 6A). This pattern of expression appeared to be similar to the one observed for the $m 8$ transcript (Hinz et al. 1994). The expression of the $m 5-l a c Z$ construct was not detected in imaginal discs, possibly because essential imaginal disc-specific

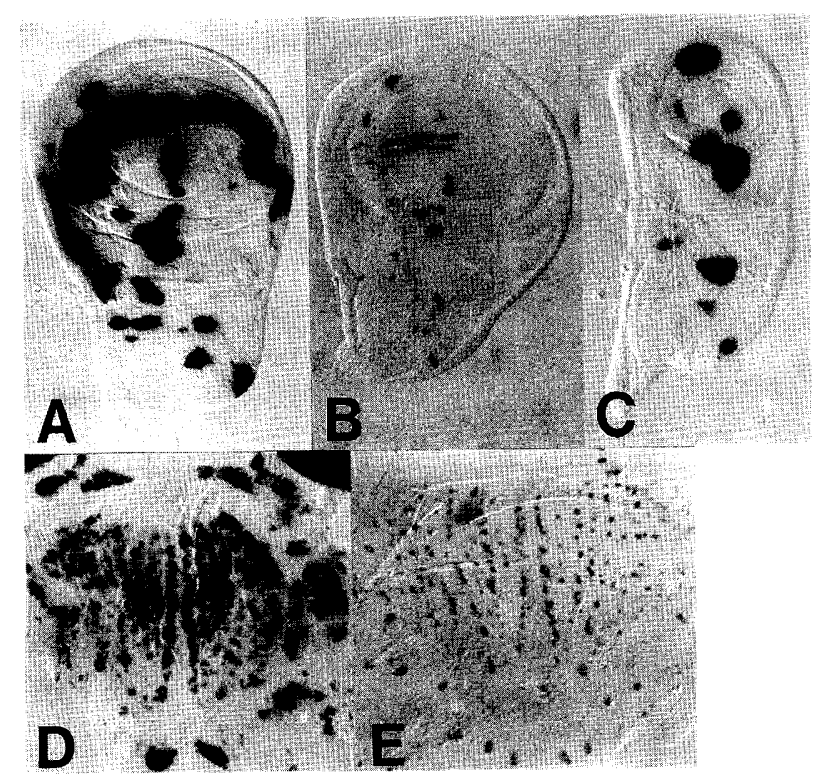

Figure 6. Regulation of the $E(\mathrm{spl})-\mathrm{C} m 8$ gene by $\mathrm{Su}(\mathrm{H})$ during imaginal development. $(A)$ In wild-type discs, m8-lacZ expression was detected in proneural cluster cells and along the wing margin. (B) lacZ expression appeared to be specific of SOPs. Thus, the deletion of the $m 8 \mathrm{Su}(\mathrm{H})$-binding sites resulted in the specific loss of lacZ expression in the non-SOP proneural cluster cells. Along the wing margin, $\beta$-galactosidase staining was not detected, except in the SOPs of the double row. (C) In $\mathrm{Su}(H)^{A R \theta} / \mathrm{Su}(H)^{S F 8}$ mutant discs, lacZ staining was observed in clusters of mutant SOPs (Schweisguth and Posakony 1992). (D) At $14 \mathrm{hr}$ after puparium formation (APF), m8-lacZ was expressed in 10 anteroposterior rows in the dorsocentral notum region. These rows presumably correspond to the microchaete proneural clusters. (E) lacZ expression appeared to be restricted to microchaete SOPs in a m8mut-lacZ pupal notum at $14 \mathrm{hr}$ APF. regulatory elements are located upstream of position -897 (Kramatschek and Campos-Ortega 1994). The presence of the $\mathrm{Su}(\mathrm{H})$-binding sites in the $\mathrm{m} 8$ promoter was essential for this expression pattern. Their deletion from the $m 8$ promoter restricted $l a c Z$ expression to singled out proneural cluster cells, namely the SOPs (Fig. 6B). In $\mathrm{Su}(H)$ mutant discs, in which most or all proneural cluster cells adopt the SOP fate (Schweisguth and Posakony 1992, 1994), m8-lacZ expression was detected in all mutant SOPs (Fig. 6C). Similar results were obtained in the developing notum for the microchaete proneural rows (Fig. 6D,E). These observations indicate that the $\mathrm{Su}(\mathrm{H})$ protein activates $E(s p l)-\mathrm{C} m 8$ transcription in the proneural cluster cells that receive $\mathrm{N}$ signaling. However, it does not seem to be required for $E$ (spl)-C $m 8$ expression in the neural precursor cells, as seen above for the SI neuroblasts (Fig. 5G,H). Finally, the expression of the $m 8-l a c Z$ construct along the wing margin was found to be strictly dependent on the $\mathrm{Su}(\mathrm{H})$-binding sites (Fig. 6B). In $S u(H)$ mutant discs, which have a reduced wing pouch region, $m 8-l a c Z$ expression was not detectable in the region where the wing margin should have formed (Fig. 6C). This suggests that $S u(H)$ may transduce the $\mathrm{N}$ signal at the wing margin (de Celis and Garcia-Bellido 1994) by the transcriptional activation of $E$ (spl)-C $\mathrm{m} 8$ expression. Hence, the direct transcriptional activation of these $E(s p l)-\mathrm{C}$ genes by $\mathrm{Su}(\mathrm{H})$ may constitute a relatively general response to $\mathrm{N}$ activation.

\section{Discussion}

This study delineates the transcriptional regulation events triggered in the nucleus by the activation of the $\mathrm{N}$ transmembrane receptor via the $\mathrm{Su}(\mathrm{H})$ DNA-binding protein. We showed a strict genetic requirement for the neurogenic activity of $\mathrm{Su}(\mathrm{H})$ in early neurogenesis. The complete lack of $\mathrm{Su}(\mathrm{H})$ function in the embryo resulted in the determination of an excess number of neuroblasts, presumably attributable to the persistent expression of the proneural genes. Finally, we identified the $E(s p l)$-C $m 5$ and $m 8$ genes as direct $\mathrm{Su}(\mathrm{H})$ downstream target genes.

The $E$ (spl)-C comprises eight neurogenic genes that display functional redundancy (Delidakis et al. 1991; Delidakis and Artavanis-Tsakonas 1992; Knust et al. 1992; Schrons et al. 1992). Two of these, the $E$ (spl)-C $m 5$ and $m 8$ genes, were shown here to be regulated directly by $\mathrm{Su}(\mathrm{H})$. It is not yet known whether the $E(s p l)-\mathrm{C} m \delta$, $m \gamma, m \beta, m 4$, or $m 7$ genes, which exhibit very similar pattern of expression in the neuroectoderm, may also be activated in a direct manner by $\mathrm{Su}(\mathrm{H})$. The identification of putative binding sites for $\mathrm{Su}(\mathrm{H})$ in the regulatory sequence located $5^{\prime}$ to the $E(\mathrm{spl})$-C $\mathrm{m} \gamma$ - and m4-coding sequences suggests that $\mathrm{Su}(\mathrm{H})$ activates the transcription of additional $E$ (spl)-C genes directly. Importantly, the transcription of the $E(s p l)-\mathrm{C} m 5$ and $m 8$ genes was found to depend on $\mathrm{Su}(\mathrm{H})$ activity only in cells that receive $\mathbf{N}$ signaling, as in the neuroectoderm. The expression of the $E$ (spl)-C $m 8$ gene in neural precursor cells did not depend on the $\mathrm{Su}(\mathrm{H})$ activity or on the binding sites for $\mathrm{Su}(\mathrm{H})$. 
The function of the $E(s p l)-\mathrm{C} m 8$ gene in the neural precursor cells is unclear, as this gene may be the only bHLH E(spl)-C gene expressed in these cells and still appears to be genetically dispensable (Knust et al. 1992; Schrons et al. 1992; Jennings et al. 1994). Together, this indicates that the neurogenic $\mathrm{Su}(\mathrm{H})$ protein activates the transcription of the $E(s p l)-C m 5$ and $m 8$ genes in response to $\mathrm{N}$ signaling. The lack of transcription of the $E(s p l)-\mathrm{C}$ genes seen in the $S u(H)$ mutant embryos may account for the deregulation of proneural gene expression (Campos-Ortega 1993). Thus, the neurogenic phenotype exhibited by the $S u(H)$ mutant embryos may result indirectly from the defective regulation of the $E($ spl)-C genes.

Proneural genes are also known to regulate in a direct manner the expression of the $E(s p l)-\mathrm{C} m 5$ and $m 8$ genes in the ventral neuroectoderm (Hinz et al. 1994; Kramatschek and Campos-Ortega 1994; see also Singson et al. 1994). Therefore, the $\mathrm{Su}(\mathrm{H})$ protein might cooperate with proneural proteins to control the spatial pattern of $E$ (spl)-C transcription in the embryo. In this view, $\mathrm{N}$ signaling might only be effective in cells with proneural potential. Therefore, the spatiotemporal regulation of the proneural genes activity might restrict a cell's ability to respond to $\mathrm{N}$ activation. Such a control mechanism might be important during inductive signaling to determine which cells will respond productively to the activation of $\mathrm{N}$.

The function of $\mathrm{Su}(H)$ in mediating $\mathbf{N}$ activation is entirely consistent with previous genetic and molecular results that implicate $\mathrm{Su}(\mathrm{H})$ in the transduction of the $\mathrm{N}$ signal (Fortini and Artavanis-Tsakonas 1994; Schweisguth 1995). It is likely that direct regulation of the $\mathrm{N}$ signaling target genes by $\mathrm{Su}(\mathrm{H})$ has been conserved during evolution. Cell transfection experiments indicate that the human homolog of $\mathrm{Su}(\mathrm{H})$ mediates the N-dependent transcriptional activation of HES-1, a possible homolog of $E$ (spl) in mammals (Jarriault et al. 1995). In addition, recent data show that the Caenorhabditis elegans homolog of $\mathrm{Su}(\mathrm{H}), \mathrm{lag}-1$, may transduce the signal from the $\mathrm{N}$ family receptor glp-1 (S. Christensen, V. Kodoyianni, and J. Kimble, pers. comm.). However, no $C$. elegans homolog of the $E(s p l)-C$ genes have been described so far.

The $\mathrm{N}$ receptor has been proposed to be a multifunctional receptor that can be activated by various extracellular ligands (Rebay et al. 1991; Couso and MartinezArias 1994; Gu et al. 1995). This raises the question of whether distinct signaling pathways are activated in response to the various ligands bound by the $\mathrm{N}$ receptor. We have observed a direct transcriptional activation of the $E(s p l)-C$ genes by $S u(H)$ in three distinct signaling events during embryogenesis and imaginal disc development. The Dl protein is thought to be the ligand responsible for $\mathrm{N}$ activation in the neuroectodermal cells during early neurogenesis as well as in the proneural cluster cells during SOP selection, whereas the Serrate (Ser) protein might be a ligand for $\mathrm{N}$ at the margin of the imaginal wing disc (Speicher et al. 1994; Thomas et al. 1995). Because overexpression of Ser can compensate partially for the loss of $\mathrm{Dl}$ function during neuroblast segregation $/ \mathrm{Gu}$ et al. 1995), it is possible that $\mathrm{N}$ signaling induced by either Dl or Ser binding similarly results in the $S u(H)$ dependent transcription of the $E$ (spl)-C genes. Therefore, the transcriptional activation of the $E(s p l)-C$ genes by $\mathrm{Su}(\mathrm{H})$ may be a relatively general response to $\mathrm{N}$ activation. The similarities between the $N$ and $E(s p l)$-C mutant phenotypes in various embryonic tissues are consistent with this view (Hartenstein et al. 1992).

Still, $\mathrm{Su}(H)$ differs from $N$ in its effect on sim expression and mesectoderm specification. In the absence of $N$ function, sim is expressed at a very low level and mesectodermal cells fail to form (Menne and Klämbt 1994; Martin-Bermudo et al. 1995). This leads to the ventral expansion of the medial proneural clusters (Martin-Bermudo et al. 1995). In contrast, sim expression is little affected in $\mathrm{Su}(\mathrm{H})$ mutant embryos, and most proneural clusters do not fuse at the midline, therefore indicating that the mesectoderm forms almost normally in $S u(H)$ mutant embryos. This suggests that an $\mathrm{Su}(\mathrm{H})$-independent signaling pathway exists from the $\mathrm{N}$ receptor to the sim promoter. In this process, $\mathrm{N}$ activation is induced by the apposition of mesodermal to ectodermal cells (Leptin and Roth 1994). Because sim expression and mesectoderm formation does not depend on $\mathrm{Dl}$ zygotic activity (Martin-Bermudo et al. 1995), this hypothetical $\mathrm{Su}(\mathrm{H})$ independent pathway may be triggered by a ligand distinct from $\mathrm{Dl}$, produced by the adjacent mesodermal cells, consistent with the idea that different $\mathrm{N}$ ligands might trigger distinct signaling pathways.

An important remaining question in this signal transduction pathway is how the activity of the $\mathrm{Su}(\mathrm{H})$ protein is regulated in response to $\mathrm{N}$ activation at the membrane. As proposed earlier, the $\mathrm{N}$-dependent activity of $\mathrm{Su}(\mathrm{H})$ could be regulated at the level of its subcellular localization (Fortini and Artavanis-Tsakonas 1994; Artavanis-Tsakonas et al. 1995). The $\mathrm{N}$ protein would sequester the $\mathrm{Su}(\mathrm{H})$ transcription factor in the cytoplasm by direct protein-protein interaction. When $\mathrm{N}$ binds its extracellular ligand, $\mathrm{Su}(\mathrm{H})$ would be released from $\mathrm{N}$, leading to its nuclear translocation and to the transcriptional activation of the $E(s p l)$-C genes. Complete elimination of $\mathrm{N}$ then should result in the nuclear localization of $\mathrm{Su}(\mathrm{H})$ (Fortini and Artavanis-Tsakonas 1994). Yet, constitutive signaling is not observed in $N$ mutant embryos. Therefore, this model needs an additional regulatory step, namely the activation of $S u(H)$ function by $\mathrm{N}$ signaling.

Another non-exclusive possibility is that the ability of $\mathrm{Su}(\mathrm{H})$ to function as a transcriptional activator could be the target of $\mathrm{N}$ regulation. Indeed, the human $\mathrm{Su}(\mathrm{H})$ protein is a transcriptional repressor (Dou et al. 1994; Hsieh and Hayward 1995/. Its transcriptional repression domain is conserved in the Drosophila protein (Hsieh and Hayward 1995). This repression function is in striking contrast with the role of $\mathrm{Su}(\mathrm{H})$ in activating the transcription of the E(spl)-C genes in Drosophila, as described here. However, the human $\mathrm{Su}(\mathrm{H})$ repressor may also function as a transcriptional activator, providing that a second protein binds to its repression domain, 
thereby inactivating it, and brings an activation domain to this DNA-bound complex (Hsieh and Hayward 1995). Such coactivators of the Drosophila $\mathrm{Su}(\mathrm{H})$ protein, which would be activated by $\mathrm{N}$, are not yet known. Alternatively, it is tempting to speculate that the $\mathrm{N}$ intracellular domain, a constitutively activated form of $\mathrm{N}$ that binds to $\mathrm{Su}(\mathrm{H}$ ) (Fortini and Artavanis-Tsakonas 1994) and localizes in the nucleus (Fortini et al. 1993; Lieber et al. 1993; Struhl et al. 1993), may be one such coactivator. Consistent with this view, Jarriault et al. (1995) recently showed that activated forms of mNotch can be found associated with human $\mathrm{Su}(\mathrm{H})$ bound on DNA, and that activated mNotch up-regulates the activity of the HES-1 promoter with a binding site for human $\mathrm{Su}(\mathrm{H})$. To be valid in vivo, this model requires the proteolytic cleavage of the $\mathrm{N}$ transmembrane receptor with ligand binding that would generate an activated form of N. Immunolocalization studies in Drosophila have so far failed to detect a processed form of $\mathrm{N}$ in the nucleus, and currently it is unknown whether proteolytic cleavage regulates $\mathrm{N}$ signaling (Artavanis-Tsakonas et al. 1995). The analysis of the possible nuclear translocation of the $\mathrm{Su}(\mathrm{H})$ protein during development, and of its transcriptional activation function at the promoters of the $E$ (spl)-C genes, should provide insights into these possible mechanisms.

\section{Materials and methods}

\section{Drosophila stocks}

Flies were cultured on standard yeast/cornmeal/sugar/agar medium at $25^{\circ} \mathrm{C}$. Flies of the genotype $w^{1118}$ were used as wild-type flies. The recombinant $\mathrm{Su}(H)^{S F 8} \mathrm{P}\left[1 \mathrm{lacZ} ; \mathrm{w}^{+}\right] \mathrm{Al}$-29 FRT40A was described in Schweisguth and Posakony (1994). The hs-FLP1, FRT40A, and $\mathrm{P}\left\{\mathrm{OVO}^{D 1}\right\} 13 \times 13$ constructs were all described previously (Chou and Perrimon 1992; Xu and Rubin 1993). Germline clones were produced in $w^{1118} / w^{1118} h s-F L P 1 ; S u(H)^{S F 8}$ $\mathrm{P}\left[\right.$ lacZ; $\left.w^{+}\right] \mathrm{A} 1-29$ FRT40A/P[ovo $\left.{ }^{D 1}\right] 13 \times 13$ FRT40A /Chou and Perrimon 1992; Schweisguth and Posakony 1994). FLP-mediated recombination was heat-induced twice $24-48$ and $48-72 \mathrm{hr}$ after egg-laying larvae, as described previously (Schweisguth 1995). These females were crossed to $w^{1118} / Y ; S u(H)^{A R 9} / C y O$ wg-lacZ, $w^{1118} / \mathrm{Y} ; \mathrm{Su}(H)^{A R 9} / C y O ; \mathrm{P}\left[w^{+}, \operatorname{lacZ}\right]-439 /+, w^{1118} /$ $\mathrm{Y} ; \mathrm{Su}(H)^{S F 8} \mathrm{P}[\mathrm{m} 8-1 a c Z]-1 / C y O w g-l a c Z$ or $w^{1118} / \mathrm{Y} ; S u(H)^{A R 9}$ $\mathrm{P}[\mathrm{m}$ 5-lacZ]15-5/CyO wg-lacZ males. Both the SF8 and AR9 mutant alleles behave as null (Schweisguth and Posakony 1992) and gave identical results in the above crosses. The use of the $\mathrm{CyO}$ wingless-lacZ [a gift of A. Martinez-Arias, University of Cambridge, UK; wg-lacZ corresponds to $\mathrm{P}[e n]-11$ (Kassis et al. 1992)] balancer allowed the unambiguous identification of the $\mathrm{Su}(\mathrm{H})$ homozygous mutant embryos. The enhancer-trap line 439 (a gift of M. Haenlin, CNRS, Strasbourg, France) was described previously (Kunish et al. 1994).

Mutations and chromosomes not described herein are described in Lindsley and Zimm (1992).

\section{In vitro mutagenesis}

The $m 8-615 \mathrm{Su}(\mathrm{H})$-binding site was deleted from the $m 8$ EcoRI -1166$)-D r a I(+50)$ genomic fragment by an internal SalI $(-625)-B g I I I(-597)$ deletion. This deletion alone has no significant effect on the activity of the $m 8$ promoter in transgenic flies (M. Lecourtois and F. Schweisguth, unpubl.).

The following nucleotides were deleted from the $m 8$ and $m 5$ promoter sequences by site-directed PCR mutagenesis: GTGAGAA $(m 8,-210)$, TTCCCAC $(m 8,-180)$, GCGTGGGAA (m5, - 893), TTCTCAC (m5, - 858), TTCCCACG (m5, - 302), and TCCCAC $(m 5,-139)$. The following primers were used: m8 $(-210$ and -180$)$, CTTACTTTCAGCTCGGGCCACGAGCCAC and CCCGAGCTGAAAGTAAGTACAATTTTTTCTCG; m5 (-893 and -858), CCGAATTCACACACGACGCGTCTCGAGCGGATATGAAAATCG; m5 (-302), CCAAGACGTGGTGCTCAGAA and GAGCACCACGTCTTGGCCAGC; m5 (-139), GGTTTCCTTGCACGCACAGCATAGC and GTGCGTGCAAGGAAACCAAGGAAATCG. Each deletion was verified by sequencing.

\section{Germ-line transformation}

The wild-type and mutated $-897 /+20 m 5$ and $-1166 /+87$ $m 8$ regulatory regions were subcloned into pCaSpeR $\beta$ gal (Thummel et al. 1988) as EcoRI-KpnI (CaSpeRm8-lacZ, CaSpeRm5-lacZ, and CaSpeRm5mut-lacZ) or EcoRI-BamHI, and BamHI-KpnI (CaSpeRm8mut-lacZ) fragments. The wildtype $m 5$ PCR fragments were obtained using the following primers: CTGGTACCAGGATGCTGCTCGAATGATGC and CCGAATTCGCGTGGGAAACACACGACG. Because the rate of nucleotide misincorporation after the two successive PCR amplification steps was $0.13 \%$, two completely independent wild-type and mutated m5 EcoRI $(-897)-K p n I(+20)$, and mutated $m 8$ BamHI $(-461)-K p n I+87)$ PCR-amplified fragments were used to generate two independent pCaSpeRm5, pCaSpeRm5mut, and pCaSpeRm8mut transformation plasmids. Each pair of contructs was analyzed in vitro by gel retardation and in vivo for promoter activity. Identical results were obtained for each pair. These $\mathrm{P}\left[\mathrm{w}^{+}\right]$transposable elements were introduced into the germ-line of $w^{1118}$ recipient embryos by coinjection with a $\Delta 2-3$ helper plasmid. From 9 to 14 independent transformant lines were obtained and at least five lines were analyzed for each construct.

\section{Gel retardation}

The experimental conditions for the in vitro synthesis of the $\mathrm{Su}(\mathrm{H})$ proteins and for gel retardation were as previously described (Brou et al. 1994). Three 18-mer double-stranded oligonucleotides covering positions $-621 /-604,-216 /-199$, and $-191 /-174$ of the $m 8$ promoter (Klambt et al. 1989) were used as probes for the $m 8-615,-210$, and -180 binding sites. The oligonucleotide named mut differs from the $m 8-180$ oligonucleotide by a single $\mathrm{T} \rightarrow \mathrm{C}$ mutation /CTCGGTCCCCACGCCACG underlined here in the sequence of the mut oligonucleotide). Note that this mutation is present as a sequencing error in the $m 8$ data bank sequence (GenBank accession no. X16553). The wild-type and mutated m8 EcoRI -1166$)-B a m H I(-461)$, and BamHI $-461|-A s p 718|+87)$ fragments were isolated from the transformation plasmids. The $m 5$ wild-type and mutated genomic fragments were PCR amplified from pCaSpeRm5LacZ and pCaSpeRm5mut-LacZ, respectively, using the following sets of primers: fragment a, CCGAATTCGCGTGGGAAACACACGACG and CCAAGACGTGGTGCTCAGAA; fragment a $\Delta$, CCGAATTCACACACGACGCGTCTCGAGCGGATATGAAAATCG and CCAAGACGTGGTGCTCAGAA; fragment $b$ and $b \Delta$, GAGCACCACGTCTTGGCCAGC and GTGCGTGCAAGGAAACCAAGGAAATCG; fragment $\mathrm{c}$ and $\mathrm{c} \Delta$, GGTTTCCTTGCACGCACAGCATAGC and CTGGTACCAGGATGCTGCTCGAATGATGC. All fragments were gel puri- 
fied and ${ }^{32} \mathrm{P}$-labeled using the Klenow enzyme or the T4 polynucleotide kinase.

Antibody staining, $\beta$-galactosidase activity staining and in situ hybridization

Standard protocols were used for antibody staining. A polyclonal anti- $\beta$-galactosidase antibody (Cappell; diluted 1:1000) was used to reveal the expression of the 439 enhancer-trap marker (Kunish et al. 1994). The mAb 22C10 (Zipurski et al. 1984; a gift of A. Audibert, CNRS, Paris, France) was diluted $1: 250$. $\beta$-Galactosidase activity staining was as described by Romani et al. (1989). The synthesis of DIG-labeled RNA probes and in situ hybridization on embryos were as previously described (Schweisguth and Posakony 1992). The $m 5, m 7$, and $m 8$ RNA probes were synthesized in vitro using subcloned genomic E(spl)-C DNA templates, kindly provided by D. Kosman and M. Levine (University of California, San Diego). The $a c, s c$, and sim RNA probes were synthesized using cDNA clones kindly provided by J. Posakony (University of California, San Diego) and F. Jimenez (University of Madrid, Spain). The LacZ probe was synthesized from KSlac (a gift of S. Small, University of California, San Diego).

\section{Acknowledgments}

We thank A. Audibert, J.A. Campos-Ortega, M. Haenlin, F. Jimenez, E. Knust, D. Kosman, M. Levine, A. Martinez-Arias, J. Posakony, S. Small, C. Thummel, and the Bloomington Stock Center for DNA, antibodies, and fly stocks. We are particularly indebted to B. Kramatschek and J.A. Campos-Ortega for communicating to us the unpublished sequence of the $E(s p l)-\mathrm{C} \mathrm{m} 5$ promoter. We also thank A. Israël, J. Kimble, and A. MartinezArias for discussions and communication of unpublished results, and members of our laboratory for critical reading. We are grateful to J.-A. Lepesant for encouragement and support. This work was supported by the Association pour la Recherche contre le Cancer and the Centre National de la Recherche Scientifique.

The publication costs of this article were defrayed in part by payment of page charges. This article must therefore be hereby marked "advertisement" in accordance with 18 USC section 1734 solely to indicate this fact.

\section{References}

Artavanis-Tsakonas S., K. Matsuno, and M.E. Fortini. 1995. Notch signaling. Science 268: 225-232.

Brou C., F. Logeat, M. Lecourtois, J. Vandekerckhove, P. Kourilsky, F. Schweisguth, and A. Israël. 1994. Inhibition of the DNA-binding activity of Drosophila Suppressor of Hairless and of its human homolog, KBF2/RBP-Jk, by direct proteinprotein interaction with Drosophila Hairless. Genes \& Dev. 8: 2491-2503.

Campos-Ortega J.A. 1993. Early neurogenesis in Drosophila melanogaster. In The development of Drosophila melanogaster (ed. M. Bate and A. Martinez-Arias), pp. 1091-1129. Cold Spring Harbor Laboratory Press, Cold Spring Harbor, New York.

Chou T.-B. and N. Perrimon. 1992. Use of a yeast site-specific recombinase to produce female germline chimeras in Drosophila. Genetics 131: 643-653.

Coffman C., W. Harris, and C. Kintner. 1990. Xotch, the Xenopus homolog of Drosophila Notch. Science 249: 1438-1441.

Couso J.P. and A. Martinez-Arias. 1994. Notch is required for wingless signaling in the epidermis of Drosophila. Cell 79: 259-272.

de Celis J.F. and A. Garcia-Bellido. 1994. Roles of the Notch gene in Drosophila wing morphogenesis. Mech. Dev. 46: $109-122$.

de la Concha A., U. Dietrich, D. Weigel, and J.A. Campos-Ortega. 1988. Functional interactions of neurogenic genes of Drosophila melanogaster. Genetics 118: 499-508.

Delidakis C. and S. Artavanis-Tsakonas. 1992. The Enhancer of split [E(spl)] locus of Drosophila encodes seven independent helix-loop-helix proteins. Proc. Natl. Acad. Sci. 89: 87318735.

Delidakis C., A. Preiss, D.A. Hartley, and S. Artavanis-Tsakonas. 1991. Two genetically and molecularly distinct functions involved in early neurogenesis reside within the Enhancer of split locus of Drosophila melanogaster. Genetics 129: 803-823.

Dou S., X. Zeng, P. Cortes, H. Erdjument-Bromage, P. Tempst, T. Honjo, and L.D. Vales. 1994. The recombination signal sequence-binding protein RBP-2N functions as a transcriptional repressor. Mol. Cell. Biol. 14: 3310-3319.

Fortini M.E. and S. Artavanis-Tsakonas. 1994. The Suppressor of Hairless protein participates in Notch receptor signaling. Cell 79: 273-282.

Fortini M.E., I. Rebay, L.A. Caron, and T.S. Artavanis. 1993. An activated Notch receptor blocks cell-fate commitment in the developing Drosophila eye. Nature 365: 555-557.

Gu Y., N.A. Hukriede, and R.G. Fleming. 1995. Serrate expression can functionally replace Delta activity during neuroblast segregation in the Drosophila embryo. Development 121: 855-865.

Hartenstein A.Y., A. Rugendorff, U. Tepass, and V. Hartenstein. 1992. The function of the neurogenic genes during epithelial development in the Drosophila embryo. Development 116: 1203-1220.

Henkel T., P.D. Ling, S.D. Hayward, and M.G. Peterson. 1994. Mediation of Epstein-Barr virus EBNA2 transactivation by recombination signal-binding protein J $\mathrm{K}$. Science 265: 9295.

Hinz U., B. Giebel, and J.A. Campos-Ortega. 1994. The basichelix-loop-helix domain of Drosophila lethal of scute protein is sufficient for proneural function and activates neurogenic genes. Cell 76: 77-87.

Hou X.S., T.-B. Chou, M.B. Melnick, and N. Perrimon. 1995. The torso receptor tyrosine kinase can activate raf in a rasindependent pathway. Cell 81: 63-71.

Hsieh J.J.-D. and S.D. Hayward. 1995. Masking of the CBF1/ RBPJא transcriptional repression domain by Epstein-Barr virus EBNA2. Science 268: 560-563.

Jarriault S., C. Brou, F. Logeat, E.H. Schroeter, R. Kopan, and A. Israël. 1995. Signaling downstream of activated mNotch. Nature 377: 355-358.

Jennings B., A. Preiss, C. Delidakis, and S. Bray. 1994. The Notch signaling pathway is required for Enhancer of split bHLH protein expression during neurogenesis in the Drosophila embryo. Development 120: 3537-3548.

Kassis J.A., E. Noll, E.P. VanSickle, W.F. Odenwald, and N. Perrimon. 1992. Altering the insertional specificity of a Drosophila transposable element. Proc. Natl. Acad. Sci. 89: 1919-1923.

Klambt C., E. Knust, K. Tietze, and J.A. Campos-Ortega. 1989. Closely related transcripts encoded by the neurogenic gene complex Enhancer of split of Drosophila melanogaster. EMBO J. 8: 203-210.

Knust E., H. Schrons, F. Grawe, and J.A. Campos-Ortega. 1992. Seven genes of the Enhancer of split Complex of Drosophila 
melanogaster encode helix-loop-helix proteins. Genetics 132: 505-518.

Kopan R., J.S. Nye, and H. Weintraub. 1994. The intracellular domain of mouse Notch: A constitutively activated repressor of myogenesis directed at the basic helix-loop-helix region of MyoD. Development 120: 2385-2396.

Kramatschek B. and J.A. Campos rtega. 1994. Neuroectodermal transcription of the Drosophila neurogenic genes $E(s p l)$ and $H L H \cdot m 5$ is regulated by proneural genes. Development 120: $815-826$.

Kunish M., M. Haenlin, and J. Campos-Ortega. 1994. Lateral inhibition mediated by the Drosophila neurogenic gene Delta is enhanced by proneural proteins. Proc. Natl. Acad. Sci. 91: 10139-10143.

Lehmann R., F. Jiménez, U. Dietrich, and J. Campos-Ortega. 1983. On the phenotype and development of mutants of early neurogenesis in Drosophila melanogaster. Wilhelm Roux's Arch. Dev. Biol. 192: 62-74.

Leptin M. and S. Roth. 1994. Autonomy and non-autonomy in Drosophila mesoderm determination and morphogenesis. Development 120: 853-859.

Lieber T., S. Kidd, E. Alcamo, V. Corbin, and M.W. Young. 1993. Antineurogenic phenotypes induced by truncated Notch proteins indicate a role in signal transduction and may point to a novel function for Notch in nuclei. Genes \& Dev. 7: 1949-1965.

Lindsley D.L. and G.G. Zimm. 1992. The genome of Drosophila melanogaster. Academic Press, San Diego, CA.

Ling P.D., J.J.-D. Hsieh, I.K. Ruf, D.R. Rawlins, and S.D. Hayward. 1994. EBNA-2 upregulation of Epstein-Barr virus latency promoters and the cellular CD23 promoter utilizes a common targeting intermediate, CBF1. I. Virol. 68: 53755383.

Martin-Bermudo M.D., A. Carmena, and F. Jimenez. 1995. Neurogenic genes control gene expression at the transcriptional level in early neurogenesis and in mesectoderm specification. Development 121: 219-224.

Martin-Bermudo M.D., C. Martinez, A. Rodriguez, and F. Jimenez. 1991. Distribution and function of the lethal of scute gene product during early neurogenesis in Drosophila. Development 113: 445-454.

Matsunami N., Y. Hamaguchi, Y. Yamamoto, K. Kuze, K. Kangawa, H. Matsuo, M. Kawaichi, and T. Honjo. 1989. A protein binding to the $\mathrm{J} \kappa$ recombination sequence of immunoglobulin genes contains a sequence related to the integrase motif. Nature 342: 934-937.

Menne T.V. and C. Klämbt. 1994. The formation of commissures in the Drosophila CNS depends on the midline cells and on the Notch gene. Development 120: 123-133.

Nambu J.R., J.O. Lewis, K.A. Wharton, and S.T. Crews. 1991. The Drosophila single-minded gene encodes a helix-loophelix protein that acts as a master regulator of CNS development. Cell 67: 1157-1167.

Nye J.S., R. Kopan, and R. Axel. 1994. An activated Notch suppresses neurogenesis and myogenesis but not gliogenesis in mammalian cells. Development 120: 2421-2430.

Rebay I., R.J. Fleming, R.G. Fehon, L. Cherbas, P. Cherbas, and T.S. Artavanis. 1991. Specific EGF repeats of Notch mediate interactions with Delta and Serrate: Implications for Notch as a multifunctional receptor. Cell 67: 687-699.

Rebay I., R.G. Fehon, and S. Artavanis-Tsakonas. 1993. Specific truncations of Drosophila Notch define dominant activated and dominant negative forms of the receptor. Cell 74: 319329.

Romani S., S. Campuzano, E.R. Macagno, and J. Modolell. 1989. Expression of the achaete and scute genes in Drosophila imaginal discs and their function in sensory organ development. Genes \& Dev. 3: 997-1007.

Schrons H., E. Knust, and J.A. Campos-Ortega. 1992. The Enhancer of split Complex and adjacent genes in the $96 \mathrm{~F}$ region of Drosophila melanogaster are required for segregation of neural and epidermal progenitor cells. Genetics 132: 481503.

Schweisguth F. 1995. Suppressor of Hairless is required for signal reception during lateral inhibition in the Drosophila pupal notum. Development 121: 1875-1884.

Schweisguth F. and J.W. Posakony. 1992. Suppressor of Hairless, the Drosophila homolog of the mouse recombination signalbinding protein gene, controls sensory organ cell fates. Cell 69: 1199-1212.

1994. Antagonistic activities of Suppressor of Hairless and Hairless control alternative cell fates in the Drosophila adult epidermis. Development 120: 1433-1441.

Singson A., M.W. Leviten, A.G. Bang, X.H. Hua, and J.W. Posakony. 1994. Direct downstream targets of proneural activators in the imaginal disc include genes involved in lateral inhibitory signaling. Genes \& Dev. 8: 2058-2071.

Skeath J.B. and S.B. Carroll. 1992. Regulation of proneural gene expression and cell fate during neuroblast segregation in the Drosophila embryo. Development 114: 939-946.

Skeath J.B., G. Panganiban, J. Selegue, and S.B. Carroll. 1992. Gene regulation in two dimensions: The proneural achaete and scute genes are controlled by combinations of axis-patterning genes through a common intergenic control region. Genes \& Dev. 6: 2606-2619.

Speicher S.A., U. Thomas, U. Hinz, and E. Knust. 1994. The Serrate locus of Drosophila and its role in morphogenesis of the wing imaginal disc: Control of cell proliferation. Development 120: 535-544.

Struhl G., K. Fitzgerald, and I. Greenwald. 1993. Intrinsic activity of the Lin-12 and Notch intracellular domains in vivo. Cell 74: 331-345.

Tata F. and D.A. Hartley. 1993. The role of the Enhancer of split complex during cell fate determination in Drosophila. Development (Suppl.) 139-148.

Thomas U., F. Jönsson, S.A. Speicher, and E. Knust. 1995. Phenotypic and molecular characterization of $\operatorname{Ser} D$, a dominant allele of the Drosophila gene Serrate. Genetics 139: 203213.

Thummel C.S., A.M. Boulet, and H.D. Lipshitz. 1988. Vectors for Drosophila P-element-mediated transformation and tissue culture transfection. Gene 74: 445-456.

Tun T., Y. Hamaguchi, N. Matsunami, T. Furukawa, T. Honjo, and M. Kawaichi. 1994. Recognition sequence of a highly conserved DNA binding protein RBP-Jк. Nucleic Acids Res. 22: $965-971$.

Xu T. and G.M. Rubin. 1993. Analysis of genetic mosaics in developing and adult Drosophila tissues. Development 117: 1223-1237.

Zipurski S.L., T.R. Venkatesh, D.B. Teplow, and S. Benzer. 1984. Neuronal Development in the Drosophila retina: Monoclonal antibodies as molecular probes. Cell 36: 15-26. 


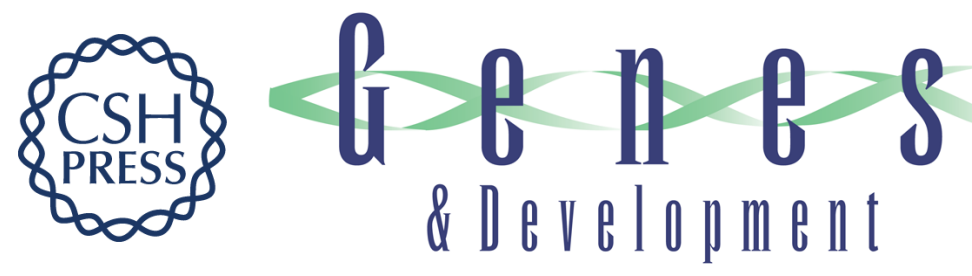

\section{The neurogenic suppressor of hairless DNA-binding protein mediates the transcriptional activation of the enhancer of split complex genes triggered by Notch signaling.}

$M$ Lecourtois and F Schweisguth

Genes Dev. 1995, 9:

Access the most recent version at doi:10.1101/gad.9.21.2598

References This article cites 53 articles, 35 of which can be accessed free at:

http://genesdev.cshlp.org/content/9/21/2598.full.html\#ref-list-1

License

Email Alerting Receive free email alerts when new articles cite this article - sign up in the box at the top Service right corner of the article or click here.

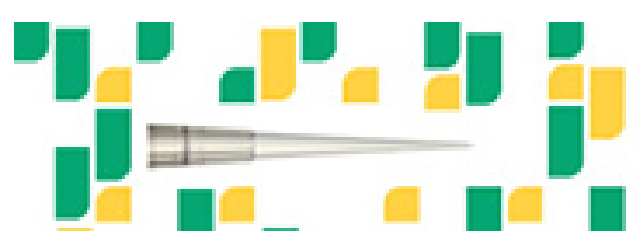

Focused on your science. 